\title{
Cultures and entrepreneurial competencies; ethnic propensities and performance in Malaysia
}

\begin{abstract}
Purpose

We examine the extent and types of entrepreneurial competences amongst culturally different ethnic groups in Malaysia. Malaysia offer us a common environment and ecosystem to make comparisons within a single context.

\section{Method}

We surveyed 600 respondents; 200 Chinese Malaysians, 200 Indian Malaysians and 200 Malays and collected data about the types of competencies and about self-reported growth as firm performance. We used PLS-SEM for inferential testing and PLS-MGA to conduct multigroup analysis among the three ethnic groups and found considerable and interesting differences.
\end{abstract}

\section{Findings}

Our nuanced, fine grained findings showed a distinctive distribution of competencies. We take the analysis further to argue that there is an ethnic disposition to favour and value different competencies. Broadly, Chinese Malaysians have a commercial outlook which contrasts with the Malaysian emphasis on social values such as family. Indian Malaysian competencies are similar to Chinese Malaysians, but with more social value emphasised. This distribution impacts on firm performance with Chinese Malaysian firms faring economically better. However, this economic measure takes no account of social measures which may be an important determinant and motivation for some ethnic groups.

\section{Implications}

Theoretically, it becomes evident that one size does not fit all. In practice, different competencies are prioritised. Hence competencies appear to be culturally shaped. Culture influences what might be seen as very practical dimensions of entrepreneuring. From a practical perspective, those encouraging entrepreneurship should take such differences into account.

Keywords: Entrepreneurial Competencies, Perceived Business growth, Malaysian Ethnic Entrepreneurs, Wholesale and Retail SMEs. 


\section{Introduction}

Global studies highlight variable small firm performance across emerging economies (Storey, 2016). These international variations in the beneficial outcomes of entrepreneurship shape our research problem. We know that the prevailing environment, the formal institutions (Harbi and Anderson, 2010) affect the type of entrepreneurship; good institutions support entrepreneurship and foster small firm growth and performance. Accordingly, some authors attribute variations to differences in the environment; however others point to different cultures. Culture can support or deter entrepreneurship in different ways. Directly it can encourage entrepreneurship, indirectly it can promote types of behaviour, even the acquisition of knowledge and skills. Wu and Li (2011) suggest the propensity towards entrepreneurship is likely a combination of economic, social and personal attributes, but especially self-efficacy. Others have demonstrated remarkable differences in the cultural appeal of entrepreneurship (Dodd et al, 2013) even in relatively similar European cultures (Kalden et al, 2017). Some literature suggests that how entrepreneurship is practiced is culturally shaped (Klyver and Foley, 2012; Anderson and Ronteau, 2017). Thus, the enactment of entrepreneurship is bound up with the economic and social context in which it occurs (McKeever et al, 2014; Anderson and Gaddefors, 2016).

It seems that entrepreneurship, and entrepreneurial performance, is a product of the entrepreneur and the context, the social and economic circumstances in which they perform (Anderson, 2000). Conceptually, this proposes a difficult research problem in untangling the effects of culture from environmental factors. Understandably, many studies avoid this problem and look only at culture or environments. In contrast, our study is able to examine ethnic differences within the same environment. Malaysia is the long-established home of three distinctive ethnic groups, so offers an experimental space for exploring the effects of cultural differences within the same context. A context where small businesses play an important economic in what Ahmad and Xavier (2012) describe as Malaysian distinct economic, cultural, values, educational, political and social environments. Moreover, Mamun et al (2018) highlight the critical role. of competencies in fulfilling their role. Indeed, this is reflected in the increasing number of Malaysian studies of competencies. Competencies are the abilities to complete a task by utilizing resources that improve performance (Mamun and Fazal, 2018) and may thus be especially important in emerging and developing economies. 
Although competencies are individual qualities, a sociological view suggests a cultural link. Historically, Weber's Protestant Work Ethic is a good example of relating business performance to culture. (Dodd and Anderson, 2001) Similarly, Redding (2008) and others describe Chinese entrepreneuring as Confucian, attributing beneficial qualities to entrepreneurial practices. Moreover, a broad view of competencies, explains competency as more than simply skills and takes full account of the ability to apply these skills in contexts (Bird, 1995, p. 51). Thus, we can readily relate the micro of competencies to the macro of culture. This can be described as the social enactment of entrepreneuring (Anderson et al, 2018) where cultures inform practices.

The very substantial 'ethnic' literature tends towards studying ethnicity within migrant groups and largely focuses on culture in contrasting entrepreneurial propensities alongside institutional contexts. For example, the interplay of economic, institutional and social processes (Senik and Vernier, 2008; Ram and Jones, 2008). Cultures, often treated in an embeddedness perspective, becomes an explanatory factor for entrepreneurial propensity and practices. For example, Levie and Hart (2013) look at the contribution made by ethnic migrants. Yet, ethnicity is actually complex and multidimensional, encompassing factors including race, heritage or descent, language, gender, and religion (Nagaraj et al., 2015), but surfaces as ethnic 'cultures'. An alternative perspective on culture treats it as a national disposition (Hayton et al 2002), often using very broad indicators such as Hofstede's cultural dimensions. A general critique of both literatures is the simplification of complex concepts and for demonstrating causality. Although we generalise ethnicity as cultural groupings, we believe that our sample size justifies our conceptual simplification of dispositions. Moreover, our focus on competencies and how they are applied highlights some of the nuances of different cultural logics.

The logic of our enquiry and research design follows the argument that cultural differences may produce different levels and possibly types of competencies. Whilst it is relatively easy to gather self-reported data about respondents' views of their competencies, these interpretations may be subject to cultural bias in how our questions are interpreted. For example, we know that native Malaysians put great store by family relationships; this we argue could colour their views and the data. Hazlina (2010) et al's study of competencies in Malaysia included what they described as the ethical dimension, including always being truthful and admitting mistakes. Whilst this may be an admirable quality in general terms, we were struck by how this might operate for the Chinese 
group, who may place great importance on 'face'. Telling the truth might involve criticism which leads to loss of face for a colleague or supplier. To work around this issue, we not only studied the competencies but also the effects. We looked at the performance of the firms alongside the entrepreneur's competencies. The literature reveals there is some debate about what constitutes competencies. Given our intention to compare competencies and their effects on performance, we elected to concentrate on the least contentious competencies and the effectiveness of their application. We collected survey data from 600 respondents, equally divided between Malaysian, Malaysian Chinese and Malaysian Indian. Ahmad (2007) proposed specific entrepreneurial competencies that suited the Malaysian context; strategic competency, opportunity competency, conceptual competency, learning competency, ethical competency, familism and personal competency (Hazlina et al., 2010).

We found the different cultures appeared to impact on both the extent and variety of competencies. The Chinese Malaysians had most competencies, closely followed by Indian Malaysians. The Malay group demonstrated only ethical, familial and conceptual. Culture had produced different priorities. In turn. Malaysian focus on largely non-commercial aspects was associated with lower firm performance.

We believe that we offer a theoretical contribution in demonstrating that competencies cannot be simply treated as universal technical skills. On the contrary, our analysis demonstrates how they are culturally underpinned. The practical implications are that developing entrepreneurship in emerging economies must take full account of cultures. Even for competencies, one size does not fit all. Nonetheless, we offer empirical evidence of the ethnic patterning of competencies and the economic results of their application.

\section{Competencies and contexts}

Bird (1995) proposed that entrepreneurial competencies are related to a venture's creation, survival and growth. Her work was followed by several studies demonstrating how businesses growth is hindered by a lack of entrepreneurial competencies (Tehseen et al., 2019; Tehseen and Ramayah, 2015; Ahmad, 2007). There is debate about the link between possessing competencies and outcomes (Mohammed et al., 2017; Dubey \& Ali, 2011; Ahmad et al., 2011a). Some argue that different contexts may influence the link (Namusonge, 2014; Ng \& Kee, 2013). 
Nonetheless, ethnic differences are well documented (e.g, Mickiewicz et al., 2019; Elo \& Hieta, 2017). Ethnic culture can shape what is valued and practiced entrepreneurially. For example, Obeng and Anderson (2017) showed how community benefits were an entrepreneurial priority for poor fisherfolk in Ghana. Moreover, Barringer and Ireland (2019) suggest different ethnic groups may have different abilities, but we argue this may also be a cultural artefact. What counts as an appropriate ability is socially constructed (Cunningham and Anderson, 2018). Accordingly looking at ethnic differences in competencies and performances should be illuminating.

The next section reviews competencies and growth for our conceptual framework and hypotheses, followed by our methods and findings. We then discuss these in the light of the arguments above and consider the contribution and limitations.

\section{Literature Review}

\section{Conceptualising Entrepreneurial Competency}

"Competency" is well established in the literature (Kaur and Bains, 2013), but has numerous descriptions and definitions. Boyatzis' (1982) highly cited book identified several types of potential competencies. He defined competency as a personal capacity that leads to behaviour that meets the job demand that brings about desired results. Moreover, "a competency may be a motive, trait, aspect of the person's self-image or social role, skill, or a body of knowledge which he or she uses" (Boyatzis, 1982, p.23). We note how such definitions extend beyond merely possessing specific skills and extend into the ability to apply them in context.

Rowe (1995) distinguishes "competence" as skills or standard of performance, whilst "competency" represents behaviour. Hoffmann (1999) observed three different ways to define competencies; (i) the standard of person's performance, result or output (ii) observable output or performance (iii) and knowledge, skills and abilities that represent the underlying attributes of a person.

\section{Concept of Business Growth}

A broadly recognised perception of performance is firm growth (Krasniqi \& Branch, 2018). Many internal and external factors impact the venture growth ( Blažková \& Dvouletý, 2019, Tehseen et al., 2019; Garnsey, Stam \& Heffernan, 2006). However, the management of these factors 
demonstrates competencies and firm growth is arguably an outcome of the competency in entrepreneurial behaviour (Greene \& Brown, 1997). Many entrepreneurship studies have used growth rate or profitability, or both, to measure venture performance (Lee \& Tsang, 2001; Jo \& Lee, 1996; Stuart \& Abetti, 1990; Begley \& Boyd, 1987). Business performance is also measured by the growth in employees or sales and/or by the increase in profits (Chandler \& Hanks, 1993; Box, White \& Barr, 1993; Gales \& Blackburn, 1990). Clearly, growth and profitability measure different aspects of performance. For instance, sometimes growth is achieved at the expense of profitability in the short run (Zahra, 1991). There is no consensus on the most appropriate performance measures of small firms (Tunberg and Anderson, 2020). Nonetheless, Wiklund (2006) argued that growth is an easily accessible indicator of performance.

\section{Development of Conceptual Model and Hypotheses}

Given the contentious views of growth and the problems of disentangling the effects of technologies and market power, we adopt Luo and Child's (2015) composition-based view (CBV) theory, well suited to smaller firms (Falahat et al., 2018), treating competencies as a resource. CBV describes growth processes in firms that do not possess the strategic assets such as brands and proprietary technologies (Luo, 2019). CBV emphasises common resources that are non-imitable and inexpensive and can be easily developed by firms to achieve growth and describes the value of combinations and use of those resources that have been viewed as common, available, or generic. This perspective makes CBV very appropriate for our comparison of Malaysian ethnic groups whose small businesses generally lack strategic assets.

Based on CBV, our conceptual model takes strategic, opportunity, learning, ethical, personal, familism, and conceptual competencies as independent variables and perceived business growth as a dependent variable as shown in Figure 1.

---- Insert Figure 1 about here ----

\section{Development of Hypotheses}

\section{H1: Impact of Strategic Competency on Business Growth}

Strategic competencies are the entrepreneurs' ability to set, evaluate and implement the firms' strategies (Rahman et al., 2014). Strategies act as a bridge to join firms' resources and capability (Ahmad et al., 2010; Parnell, Lester \& Menefee, 2000). Many studies have either conceptualised or found the positive influence of strategic competency for achieving superior performances (Nakhata, 2018; Suhaimi et al., 2018; Stephen et al., 2017; Umar \& Ngah, 2017; Yusuff et al., 2016). We thus hypothesise,

H1a: There is a positive impact of strategic competency on business growth among Malay entrepreneurs. 
H1b: There is a positive impact of strategic competency on business growth among Malaysian Chinese entrepreneurs.

H1c: There is a positive impact of strategic competency on business growth among Malaysian Indian entrepreneurs.

\section{H2: Impact of Opportunity Competency on Business Growth}

This important competency is closely related to entrepreneurship ( $\mathrm{Li}, 2009$ ). It indicates the entrepreneurs' ability to search, recognise, develop and evaluate all possible opportunities available in a market (Man, 2001; Ahmad, 2007). It represents a critical ability for the recognition and exploitation of the opportunity (Rahman et al., 2015a). Thus,

$\mathrm{H} 2 \mathrm{a}$ : There is a positive impact of opportunity competency on business growth among Malay entrepreneurs.

$\mathrm{H} 2 \mathrm{~b}$ : There is a positive impact of opportunity competency on business growth among Malaysian Chinese entrepreneurs.

$\mathrm{H} 2 \mathrm{c}$ : There is a positive impact of opportunity competency on business growth among Malaysian Indian entrepreneurs.

\section{H3: Impact of Learning Competency on Business Growth}

Zhang (2012) proposed taking entrepreneurial competencies (opportunity, relationship, organising, conceptual, strategic and commitment) as the mediator between entrepreneurial learning and entrepreneurial performance. Alternatively, entrepreneurial learning is considered a core entrepreneurial competency. Many studies have found the positive influence of learning competency on performance (Nakhata, 2018; Umar \& Ngah, 2017; Yusuff et al., 2016). Thus:

H3a: There is a positive impact of learning competency on business growth among Malay entrepreneurs.

H3b: There is a positive impact of learning competency on business growth among Malaysian Chinese entrepreneurs.

H3c: There is a positive impact of learning competency on business growth among Malaysian Indian entrepreneurs.

\section{H4: Impact of Ethical Competency on Business Growth}

Ethics arises in personal attributes as trustworthy, honest and responsible (Orme \& Ashton, 2003). Ethical competency represents an individuals' ability for honesty and transparency by admitting mistakes and telling the truth (Ahmad, Wilson, Kummerow et al., 2011b; Hazlina Ahmad et al., 
2010; Ahmad, 2007). Some studies have found the positive influence of ethical competency for performances (Osagie et al., 2016; Kaur \& Bains, 2013). Thus,

H4a: There is a positive impact of ethical competency on business growth among Malay entrepreneurs.

H4b: There is a positive impact of ethical competency on business growth among Malaysian Chinese entrepreneurs.

$\mathrm{H} 4 \mathrm{c}$ : There is a positive impact of ethical competency on business growth among Malaysian Indian entrepreneurs.

\section{H5: Impact of Personal Competency on Business Growth}

Many studies have found the positive influence of personal competency for achieving better performances (Nakhata, 2018; Quagrainie, 2018; Umar \& Ngah, 2017; Yusuff et al., 2016). Therefore:

H5a: There is a positive impact of personal competency on business growth among Malay entrepreneurs.

H5b: There is a positive impact of personal competency on business growth among Malaysian Chinese entrepreneurs.

H5c: There is a positive impact of personal competency on business growth among Malaysian Indian entrepreneurs.

\section{H6: Impact of Familism on Business Growth}

Familism indicates the individuals' identification with, and their attachment to their family and is characterised by a sense of loyalty, responsibility and solidarity among members of the family (Zeiders, Updegraff, Umaña-Taylor, McHale \& Padilla, 2016). Familism involves family closeness, family well-being and supporting family members. Kaur \& Bains (2013) defined familism as dominant concern and affection for the family that drives daily life and actions. Familism is the social organisation of obligations towards the immediate family and links kin members (Hee Park, 2004). Thus, familism is associated with loyalty and commitment towards own group (Ho \& Barnes, 2013). Moreover, familism makes work relations personal and flexibile to change (Wijaya, 2008). Her study revealed that the Malaysian entrepreneurs prioritise advice and support from their family members, sharing knowledge and resources and seek help from their loyal and trusted employees. Two recent studies have considered the influence of familism on performances (Umar \& Ngah, 2017; Kuada, 2015). Thus;

H6a: There is a positive impact of familism on business growth among Malay entrepreneurs. 
H6b: There is a positive impact of familism on business growth among Malaysian Chinese entrepreneurs.

H6c: There is a positive impact of familism on business growth among Malaysian Indian entrepreneurs.

\section{H7: Impact of Conceptual Competency on Business Growth}

Chandler \& Jansen (1992) propose conceptual competency as the mental capability to coordinate business activities and include risk-taking, decision skills, innovativeness and understanding (Yusoff et al., 2016; Man et al., 2002). Several studies have found a positive impact of conceptual competency in achieving superior firm's performances (Nakhata, 2018; Quagrainie, 2018; Suhaimi et al., 2018; Stephen et al., 2017; Umar \& Ngah, 2017; Yusuff et al., 2016). Thus:

H7a: There is a positive impact of conceptual competency on business growth among Malay entrepreneurs.

H7b: There is a positive impact of conceptual competency on business growth among Malaysian Chinese entrepreneurs.

H7c: There is a positive impact of conceptual competency on business growth among Malaysian Indian entrepreneurs.

\section{Methods}

\section{The Survey and sampling}

We used quota and snowballing to sample 600 ethnic entrepreneurs of wholesale and retail firms in four regions of West Malaysia:

1. Northern region: Perlis, Kedah, Pulau Pinang, and Perak.

2. Central region: Selangor, Melaka, Federal Territory of Kuala Lumpur, and Negeri Sembilan.

3. Eastern region: Kelantan, Terengganu, and Pahang.

4. Southern region: Johor.

The survey was administered over 11 months from 2017-18 targeting,

- entrepreneurs who started their businesses and actively engaged in its management;

- businesses were of at least three years old with 5-75 employees

- were member of our ethnic groups. 
Most Malaysian firms are small, yet represent 98.5 per cent of all businesses (Haya and Juhaini, 2018). We sampled wholesaling and retailing firms because of their important contribution towards GDP (Tehseen et al., 2019). To ensure we achieved our planned sample size, we first used personal contacts and then snowball sampling until we reached our target numbers. Enumerators from the three ethnic backgrounds delivered and collected standardised questionnaires to maximise complete responses. These enumerators had been trained to ensure correct procedures. We made appointments to deliver the questionnaires and answer any queries. Although time consuming, face-to-face contact strategy enabled us to explain the importance of a respondents' participation. Moreover, personal contact allowed us to check our sample criteria.

\section{Measurement}

All items in the constructs were adopted from existing studies, as described in our literature review. We first conducted a pilot study with colleagues and target respondents to ensure the survey's clarity. We also assessed the format, length, flow and completion time. From the feedback and our observations, we refined the questionnaire. The final instrument consisted of 30 items (Table 1). Responses were measured using a five-point Likert scale ranging from $1=$ strongly disagree to $5=$ strongly agree.

---- Insert Table 1 about here ----

\section{Descriptive Data Analysis}

A detailed profile is shown in Tables II and III.

---- Insert Tables II and III about here ----

\section{Common Method Variance}

Data were collected from similar types of respondents, so common method variance could influence the findings (Sanchez-Famoso et al., 2019; Koay, 2018, Jakobsen \& Jensen, 2015). We used two statistical remedies; Partialling Out a Marker Variable and Correlation Matrix Procedure (Tehseen et al.,2017). Lindell and Whitney (2001) proposed CMV was problem only when the correlation between a marker variable and any other constructs is more than 0.3. Correlation Matrix Procedure (Bagozzi, Yi, and Phillips, 1991) indicate CMV occurs in any study when more than 0.9 correlation exists among the principal constructs. Correlation between marker and other constructs was found less than 0.3; correlation among all principal constructs was less than 0.9. Furthermore, by using the full collinearity assessment approach recommended by Kock (2015), all factor-level 
VIFs, after conducting full collinearity test, were less than 3.3. Accordingly, the model is free of common method bias.

\section{Results}

\section{Inferential Data Analysis}

Given we analyse and predict the influence of competencies on business growth, PLS-SEM techniques are appropriate (Hair et al., 2017). Following Ramayah et al. (2017), multivariate kurtosis and skewness were analysed by using webpower software. Our data was not multivariate normal with Mardia's multivariate kurtosis score of 103.466 and Mardia's multivariate skewness of 8.923. Accordingly. we continued our non-parametric analysis using PLS-SEM techniques with SmartPLS software, version 3.2.7. Multigroup analysis was also conducted to analyse structural models among the three groups (Henseler et al., 2009).

\section{Evaluation of Measurement Model}

The constructs' internal reliability was established and all values of composite reliability, Cronbach's alpha, and Dillon-Goldstein's rho were above cut off values of 0.6. Likewise, the AVE values of all constructs were above 0.50 , which also determined their acceptable convergent validity. Table IV reveals the constructs' reliability and validity values. Furthermore, the reliability of indicators was in the acceptable range of outer loadings of 0.40-0.70 (Hair et al., 2017). All latent variables' discriminant validity was established using heterotrait-monotrait ratio (HTMT) criterion as demonstrated in Table $\mathrm{V}$.

\section{---- Insert Tables IV-V about here ----}

\section{Assessment of Structural Model}

Five tests, VIF, $f^{2}, R^{2}, Q^{2}$, and significance of relationships were conducted to assess the structural models across three groups. The values of VIF analyse the issues of collinearity were less than 5 among all latent variables in each group. Thus, collinearity issues did not occur in the current study. The bootstrapping's procedure using 1000 re-sample was employed to assess the relationships among the constructs (Ramayah et al., 2018).

\section{---- Insert Table VI about here ---}

The results in Table VI show the positive and significant impact of Strategic Competency (SC) on business growth among Malaysian Chinese $(\beta=0.151, t=1.873)$ and Indian $(\beta=0.148$, $\mathrm{t}=1.928)$ but not in Malay $(\beta=0.099, \mathrm{t}=1.492)$ entrepreneurs. Therefore, only H1a and H1b are supported, whereas H1c is rejected.

Moreover, the results show positive and significant influence of Opportunity Competency (OC) on business growth among Malaysian Chinese $(\beta=0.202, \mathrm{t}=1.918)$ but not among Malay $(\beta=0.165, \mathrm{t}=1.634)$ and Indian $(\beta=0.085, \mathrm{t}=0.724)$. Therefore, only $\mathrm{H} 2 \mathrm{a}$ is supported while $\mathrm{H} 2 \mathrm{~b}$ and $\mathrm{H} 2 \mathrm{c}$ are not supported. Findings show a positive and significant influence of Learning Competency (LC) on business growth among Malaysian Chinese $(\beta=0.146, t=2.212)$ and Indian $(\beta=0.122, t=2.029)$ entrepreneurs, whereas its negative and non-significant impact was found on business growth among Malay entrepreneurs $(\beta=-0.062, t=1.193)$. Therefore, the empirical results did not support $\mathrm{H} 3 \mathrm{c}$ but supported only $\mathrm{H} 3 \mathrm{a}$, and $\mathrm{H} 3 \mathrm{~b}$. 
Interestingly, we note the negative and non-significant influence of Ethical Competency (EC) on business growth among Malaysian Chinese $(\beta=-0.041, \mathrm{t}=0.486)$ but its positive and significant influence among Malay $(\beta=0.431, \mathrm{t}=6.489)$ and Indian $(\beta=0.183, \mathrm{t}=1.826)$ entrepreneurs. Thus, $\mathrm{H} 4 \mathrm{a}$ was rejected, whereas $\mathrm{H} 4 \mathrm{~b}$ and $\mathrm{H} 4 \mathrm{c}$ were supported.

The results show positive as well as significant impact of Personal Competency (PC) on business growth among Malaysian Chinese $(\beta=0.129, \mathrm{t}=1.913)$ and Malaysian Indian $(\beta=0.123$, $\mathrm{t}=1.938)$ entrepreneurs but not among Malay $(\beta=0.094, \mathrm{t}=1.293)$. Therefore, H5a and H5b were only supported while H5c was not supported.

However, Table 10 shows positive and significant influence of Familism (FC) on business growth among Malaysian Chinese $(\beta=0.174, \mathrm{t}=2.790)$, Malay $(\beta=0.105, \mathrm{t}=1.757)$, and Malaysian Indian $(\beta=0.126, t=1.771)$ entrepreneurs. Thus, H6a, H6b, and H6c were supported. Likewise, results also reveal positive and significant influence of Conceptual Competency (CC) on business growth among Malaysian Chinese $(\beta=0.137, t=1.764)$, Malay $(\beta=0.147, t=2.088)$, and Malaysian Indian $(\beta=0.146, t=1.935)$ entrepreneurs. Thus, $\mathrm{H} 7 \mathrm{a}, \mathrm{H} 7 \mathrm{~b}$, and $\mathrm{H} 7 \mathrm{c}$ were also supported.

We determined the seven constructs' predictive capability on business growth through $R^{2}$ values across the three samples. The $R^{2}$ value in Malay sample is 0.492 . but $R^{2}$ values in Chinese and Indian samples are 0.371 and 0.385 respectively. We also conducted the procedure of blindfolding to obtain $Q^{2}$ values for business growth. The predictive relevance of the samples' models was established across all three groups with $Q^{2}$ values above 0 (Hair et al., 2017). In the Malay sample $Q^{2}$ is 0.283; Malaysian Chinese sample 0.207 and Indian sample 0.217.

The values of $f^{2}$ effect sizes of seven predictor variables were also assessed to reveal their effects on business growth. Table 6 shows Malay sample, CC ( $f^{2}$ of 0.025$)$ and OC $\left(f^{2}\right.$ of 0.035$)$ have a small effect on BG, whereas EC ( $f^{2}$ of 0.238$)$ has a larger effect on BG. The other predictors having $f^{2}$ effect sizes of less than 0.02 are not considered as important predictors for BG. Similarly, in Malaysian Chinese sample, OC ( $f^{2}$ of 0.045 ) has only moderate effect on BG, whereas other predictors having $f^{2}$ effect sizes of less than 0.02 namely $\mathrm{CC}$ and $\mathrm{EC}$ are not considered important for BG, while other predictors including FC, LC, PC, and SC had a small effect on BG. Likewise, results reveal small effects of CC, EC, LC, PC, and SC on BG in Malaysian Indian sample whose $f^{2}$ effect sizes values 0.02. Conversely, $\mathrm{FC}$ and $\mathrm{OC}$ are not considered important for BG because their $f^{2}$ effect sizes are less than minimum value of 0.02 . Table 6 also shows the $f^{2}$ effect sizes of the constructs.

\section{Multigroup Analysis}

The purpose of multigroup analysis is to compare explained variance and structural path relationships across groups (Hernández-Perlines, 2016). Prior to the multigroup analysis, measurement invariance was also established across groups using MICOM (Henseler et al., 2016). Once the measurement invariance was established, the multigroup analysis was conducted using Henseler's MGA (Henseler et al., 2009). We employed Henseler's MGA to compare bootstrapped

estimates from each bootstrapped sample (Rasoolimanesh et al., 2016; Hair et al., 2018). The 
findings of Henseler's MGA revealed the significant differences between a few relationships, Table VII.

---- Insert Table VII about here ---

\section{Findings}

Based on our comparative analysis of Malaysian ethnic groups we provide empirical evidence about the positive and significant impact of familism and conceptual competencies on business growth. Moreover, strategic, learning and personal competencies have positive and significant influence on business growth among Malaysian Chinese and Malaysian Indian entrepreneurs. Ethical competency has a positive and significant impact on business growth among Malay and Malaysian Indian entrepreneurs.

However, opportunity competency has a significant impact on business success only among Malaysian Chinese entrepreneurs. strategic, learning, and personal competencies are found to have their positive as well as non-significant impact on business growth among Malay entrepreneurs. The PLS-MGA reveals little difference amongst the ethnic groups regarding the impact of entrepreneurial competencies on business growth. There is a modest, but significant difference for the influence of opportunity, learning, familism, and conceptual competencies among Malaysian Chinese and Malay entrepreneurs. There is also a small, but significant difference in the influence of strategic, ethical, and personal competencies on business growth among Malaysian Indian and Malay entrepreneurs.

\section{Discussion and Conclusions}

We note the very different distribution of competencies by ethnicity. Moreover, we can also see the impact on performance. We have to conclude that culture, as manifest in ethnicity, has a major effect on both the type of competency and its commercial impact. We note the argument that Malay entrepreneurs are closely attached with their traditions and customs and are perceived as more conservative as compared to Malaysian Chinese and Malaysian Indian entrepreneurs (Jamil et al., 2014; Terpstra-Tong et al., 2014). For us it seems that these cultural traditions may have a detrimental effect on Malay form performance if measured economically. Yet, economic performance is only one dimension and we have taken no account of social or family responsibility as a performance. This seems to suggest that further studies should consider broader, more socially complete indicators of performance. Moreover, ours is necessarily a broad approach which may oversimplify nuanced effects of culture. It would be interesting then to look at these differences, especially the processes, more closely in a qualitative approach.

Nonetheless our study contributes to the existing literature of entrepreneurial competencies and business growth by providing the finer-grained analysis regarding the impact of seven context based entrepreneurial competencies (i.e., strategic, opportunity, learning, ethical, personal, familism, and conceptual competencies) on business growth among three dominant ethnic groups

of Malaysian entrepreneurs. Existing Malaysian studies have provided empirical evidence of the 
positive impact of entrepreneurial competencies on firm's performance (Ahmad et al., 2018; Umar et al., 2017; Mohsin et al., 2015; Ahmad et al., 2010; Ahmad, 2007). However, our more detailed analysis fills, as well as contributes, to a detailed research gap based on sophisticated statistical techniques.

Conceptually, our findings appear to offer evidence that cultures matter. The influence of tradition, and the values within that tradition, seems manifest in shaping what competencies are developed. To push this proposal, it seems that Chinese Malaysians have a commercial culture; Malays seem to value ethics and family to create a less individualistic culture. Indian Malays are close to Chinese Malays, but tempered by some more social values.

\section{Practical Implications}

The practical implications are limited because culture is so deep rooted. Nonetheless, being aware of the different values that underpin different competencies may highlight what may need to be addressed to promote performance, but also how this should be tackled. We see this largely as a policy implication, that any single measure to further entrepreneurship ought to take account of ethnic cultural priorities. Nonetheless, for practitioners, awareness could promote reflection on practices by the different ethnic groups. These may be so embedded as to be taken for granted, so that their value and disadvantages may not be considered.

\section{Limitations and Directions for Future Research}

This study has some limitations. We only used a few types of entrepreneurial competencies. Although the literature had indicated these as the most relevant for this context, as yet unrecognised competencies may be important. Exploratory, perhaps ethnographic work focusing on practices, could uncover interesting relationships. As we explained earlier, qualitative approaches would usefully study the nuances of the cultural and practice relationships

Moreover, the study's findings of weak impacts of some of the entrepreneurial competencies on business growth may indicate the possibility of moderators in the relationships. Thus, researchers could explore potential moderators such as government support, network competence and market turbulence to better explain the relationship between entrepreneurial competencies and business growth. Furthermore, as one of the paper's reviewers suggested, looking within the ethnic groups for differences by age or gender could also be fruitful.

Nonetheless, we believe that this study has identified some cultural roots that help explain differences in Malaysian business performance. Moreover, we have added empirical strength to the general argument that culture matters.

\section{References}


Ahmad, N. H. (2007), “A Cross Cultural Study of Entrepreneurial Competencies and Entrepreneurial Success in SMEs in Australia and Malaysia", (doctoral dissertation). The University of Adelaide, Adelaide, South Australia.

Ahmad, Z.S., and Xavier, S. R. (2012), "Entrepreneurial environments and growth: evidence from Malaysia GEM data", Journal of Chinese Entrepreneurship, Vol.4, No.1, pp.50-69.

Ahmad, N. H., Wilson, C. and Kummerow, L. (2011a), "Assessing the Dimensionality of Business Success: The Perspectives of Malaysian SME Owner-Managers”, Journal of Asia-Pacific Business, Vol.12, No.3, pp.207-224.

Ahmad, N. H., Wilson, C., Kummerow, L., et al. (2011b), “A Cross-Cultural Insight into the Competency-Mix of SME Entrepreneurs in Australia and Malaysia", International Journal of Business and Management Science, Vol.4, No.1, pp.33-50.

Ahmad, N.H., Suseno, Y., Seet, P.S., Susomrith, P. and Rashid, Z. (2018), "Entrepreneurial competencies and firm performance in emerging economies: a study of women entrepreneurs in Malaysia", in Ratten, V., Braga, V. and Marques, C. (Eds), Knowledge, Learning and Innovation, Contributions to Management Science, Springer, Cheltenham.

Allred, S. B. and Ross-Davis, A. (2011), "The Drop-Off and Pick-Up Method: An Approach to Reduce Nonresponse Bias in Natural Resource Surveys", Small-Scale Forestry, Vol. 10, No. 3, pp. 305-318.

Anderson, A.R., (2000), "The protean entrepreneur: the entrepreneurial process as fitting self and circumstance", Journal of Enterprising Culture, Vol.8, No.03, pp.201-234.

Anderson, A. and Gaddefors, J., (2016), "Entrepreneurship as a community phenomenon; reconnecting meanings and place", International Journal of Entrepreneurship and Small Business, Vol.28, No.4, pp.504-518.

Anderson, A. and Ronteau, S., (2017), "Towards an entrepreneurial theory of practice; emerging ideas for emerging economies", Journal of Entrepreneurship in Emerging Economies, Vol.9, No.2, pp.110-120.

Anderson, A.R. and Obeng, B.A., (2017), "Enterprise as socially situated in a rural poor fishing community", Journal of rural studies, Vol.49, pp.23-31.

Anderson, A.R., Warren, L. and Bensemann, J., (2018), "Identity, enactment, and entrepreneurship engagement in a declining place", Journal of Small Business Management. DOI: $10.1111 /$ jsbm.12406

Barringer, B.R. and Ireland, R.D. (2019), Entrepreneurship: Successfully Launching New Ventures. $6^{\text {th }}$ ed. New Jersey: Pearson Prentice-Hall.

Bagozzi, R. P., Yi, Y. and Phillips, L. W. (1991), “Assessing Construct Validity in Organizational Research", Administrative Science Quarterly, pp.421-458.

Bird, B. (1995), "Toward a theory of entrepreneurial competency", in Katz, J.A. and Brockhaus, R.H. (Eds), Advances in Entrepreneurship, Firm emergence, and Growth, Vol. 2, JAI Press, Greenwich, CT, pp. 51-72

Begley, T. M and Boyd, D. P. (1987), "Psychological Characteristics Associated with Performance in Entrepreneurial Firms and Smaller Businesses", Journal of Business Venturing, Vol.2, No.1, pp.79-93.

Bergevoet, R. and Woerkum, C. V. (2006), "Improving the Entrepreneurial Competencies of Dutch Dairy Farmers through the Use of Study Groups", Journal of Agricultural Education and Extension, Vol.12, No.1, pp.25-39. 
Bertrand, M. and Schoar, A. (2006), "The Role of Family in Family Firms", The Journal of Economic Perspectives, Vol.20, No.2, pp.73-96.

Blažková, I. and Dvouletý, O. (2019), "Investigating the differences in entrepreneurial success through the firm-specific factors", Journal of Entrepreneurship in Emerging Economies, Vol.11, No.2, pp.154-176

Brinckmann, J. (2008). Competence of Top Management Teams and Success of New TechnologyBased Firms. Deutscher Universitäts-Verlag, Wiesbaden, Germany.

Boyatzis, R. E. (1982). The Competent Manager: A Model for Effective Performance. New York: John Wiley \& Sons.

Box, T. M., White, M. A. and Barr, S. H. (1993), “A Contingency Model of New Manufacturing Firm Performance”, Entrepreneurship: Theory and Practise, Vol.18, No.2, pp.31-46.

Brush, C. G. and Vanderwerf, P. A. (1992), "A Comparison of Methods and Sources for Obtaining Estimates of New Venture Performance”, Journal of Business Venturing, Vol.7, No.2, pp.157-170.

Chandler, G. N. and Jansen, E. (1992), “The Founder's Self-Assessed Competence and Venture Performance", Journal of Business Venturing, Vol.7, No.3, pp.223-236.

Chandler, G. N. and Hanks, S. H. (1993), "Measuring the Performance of Emerging Businesses: A Validation Stud", Journal of Business Venturing, Vol.8, No.5, pp.391-408.

Choi, Y.R. and Shepherd, D. A. (2004), "Entrepreneurs' Decisions to Exploit Opportunities", Journal of Management, Vol.30, No.3, pp.377-395.

Cooper, A. C. (1993), "Challenges in Predicting New Firm Performance", Journal of Business Venturing, Vol.8, No.3, pp.241-253.

Cunningham, J. and Anderson, A.R., (2018), "Inspired or Foolhardy: Sensemaking, Confidence and Entrepreneurs' Decision-Making”, Group Decision and Negotiation, Vol.27, No.3, pp.393-415.

Dodd, S.D., Jack, S. and Anderson, A.R., (2013), "From admiration to abhorrence: the contentious appeal of entrepreneurship across Europe", Entrepreneurship \& Regional Development, Vol.25, No.1-2, pp.69-89.

Dodd, S.D. and Anderson, A.R., (2001), "Understanding the enterprise culture paradigm: paradox and policy", The International Journal of Entrepreneurship and Innovation, Vol.2, No.1, pp.13-26.

Dubey, R. and Ali, S.S. (2011), "Study on effect of functional competency on performance of Indian manufacturing sector", International Journal of Engineering Business Management, Vol. 3 No. 3, pp. 1-15.

El Harbi, S. and Anderson, A.R., (2010), "Institutions and the shaping of different forms of entrepreneurship", The Journal of socio-economics, Vol.39, No.3, pp.436-444.

Elo, M., and Hieta, H. (2017), "From ethnic enclaves to transnational entrepreneurs: the American dream of the Finns in Oregon, USA". International Journal of Entrepreneurship and Small Business, Vol.31, No. 2, pp.204-226.

Fombrun, C. J. and Wally, S. (1989), "Structuring Small Firms for Rapid Growth", Journal of Business Venturing, Vol.4, No.2, pp.107-122.

Falahat, M., Tehseen, S., and Van Horne, C. (2018), "Entrepreneurial Innovativeness and its Impact on SMEs' Performances", International Journal of Entrepreneurship, Vol.22, No.3, pp.1-9. 
Gales, L. M., and Blackburn, R. S. (1990), "An analysis of the impact of supplier strategies and relationships on small retailer actions, perceptions, and performance", Entrepreneurship Theory and Practice, Vol.15, No.1, pp.7-22.

Garnsey, E., Stam, E. and Heffernan, P. (2006), "New Firm Growth: Exploring Processes and Paths", Industry and Innovation, Vol.13, No.1, pp.1-20.

Greene, P. G. and Brown, T. E. (1997), "Resource Needs and the Dynamic Capitalism Typology", Journal of Business Venturing, Vol.12, No.3, pp.161-173.

Hayton, J.C., George, G. and Zahra, S.A., 2002. National culture and entrepreneurship: A review of behavioral research. Entrepreneurship theory and practice, 26(4), pp.33-52.

Hair, J.F., Sarstedt, M., Ringle, C.M. and Gudergan, S.P. (2018), Advanced issues in partial least squares structural equation modeling (3rd ed.). Thousand Oaks, CA: Sage.

Hair, J.F., Hult, G.T.M., Ringle, C.M. and Sarstedt, M. (2017), A primer on partial least squares structural equation modeling (PLS-SEM) (2nd ed.). Thousand Oaks, CA: Sage.

Hazlina Ahmad, N., Ramayah, T., Wilson, C. and Kummerow, L. (2010), "Is Entrepreneurial Competency and Business Success Relationship Contingent upon Business Environment? A Study of Malaysian SMEs", International Journal of Entrepreneurial Behavior \& Research, Vol.16, No.3, pp.182-203.

Haya, P.N. and Juhaini, J. (2018), "The impact of government enhancement programs towards SME performance in Malaysia”, Journal of Fundamental and Applied Sciences, Vol. 10, No. 6S, pp. 1679-1695.

Henseler, J., Ringle, C.M. and Sarstedt, M. (2016), “Testing measurement invariance of composites using partial least squares". International Marketing Review, Vol. 33 No. 3, pp. 405-431.

Hee Park, T. (2004), "The Influences of Familism on Interpersonal Trust of Korean Public Officials", International Review of Public Administration, Vol.9, No.1, pp.121-135.

Henseler, J., Ringle, C. M. and Sinkovics, R. R. (2009), "The Use of Partial Least Squares Path Modeling in International Marketing", Advances in International Marketing, Vol.20, No.1, pp.277-319.

Hernández-Perlines, F. (2016), "Entrepreneurial Orientation in Hotel Industry: Multi-Group Analysis of Quality Certification", Journal of Business Research, pp.1-11.

Ho, P. and Barnes, L. (2013), "An Examination of How Entrepreneurs in Hong Kong Perceive Personal Success through Business Activities", Journal of Marketing Development and Competitiveness, Vol.7, No.1, pp.63-72.

Hoffmann, T. (1999), “The Meanings of Competency”, Journal of European Industrial Training, Vol.23, No.6, pp.275-286.

Jakobsen, M. and Jensen, R. (2015), "Common Method Bias in Public Management Studies", International Public Management Journal, Vol.18, No.1, pp.3-30.

Jamil, A., Omar, R. and Panatik, S. A. (2014), "Entrepreneurial Passion, Achievement Motivation Goals and Behavioural Engagements in Malaysia: Are There Any Differences across Ethnic Groups?" Asian Social Science, Vol.10, No.17, pp.17-28.

Jo, H. and Lee, J. (1996), "The Relationship between an Entrepreneur's Background and Performance in a New Venture", Technovation, Vol.16, No.4, pp.161-211.

Kalden, J. N., Cunningham, J., and Anderson, A. R. (2017), "The social status of entrepreneurs: Contrasting German perspectives", The International Journal of Entrepreneurship and Innovation, Vol.18, No. 2, pp.91-104. 
Kaur, H., and Bains, A. (2013), "Understanding the concept of entrepreneur competency", Journal of Business Management \& Social Sciences Research, Vol.2, No11, pp.31-33.

Klyver, K. and Foley, D., (2012), "Networking and culture in entrepreneurship", Entrepreneurship \& Regional Development, Vol.24, No.7-8, pp.561-588.

Koay, K. Y. (2018), “Understanding consumers' purchase intention towards counterfeit luxury goods: An integrated model of neutralisation techniques and perceived risk theory", Asia Pacific Journal of Marketing and Logistics, Vol.30, No.2, pp.495-516.

Krasniqi, B. and Branch, D. (2018), "Institutions and firm growth in a transitional and post-conflict economy of Kosovo", Journal of Entrepreneurship in Emerging Economies, on line. doi.org/10.1108/JEEE-05-2017-0034

Kuada, J. (2015), "Theories and Perspectives on Entrepreneurship", In Private Enterprise-Led Economic Development in Sub-Saharan Africa (pp. 153-163). Palgrave Macmillan UK.

Kock, N. (2015), "Common method bias in PLS-SEM: A full collinearity assessment approach", International Journal of e-Collaboration (IJeC), Vol.11, No.4, pp.1-10.

Lee, D. Y. and Tsang, E. W. (2001), "The Effects of Entrepreneurial Personality, Background and Network Activities on Venture Growth", Journal of Management Studies, Vol.38, No.4, pp.583-602.

Levie, J., \& Hart, M. (2013). The contribution of migrants and ethnic minorities to entrepreneurship in the United Kingdom.in The Dynamics of Entrepreneurship: Evidence from Global Entrepreneurship Monitor Data, eds. Levie, J. and Hart, M., pp.101-123.

Li, X. (2009), Entrepreneurial Competencies as an Entrepreneurial Distinctive: An Examination of the Competency Approach in Defining Entrepreneurs (master's thesis). Singapore Management University.

Lindell, M. K. and Whitney, D. J. (2001), “Accounting for Common Method Variance in CrossSectional Research Designs", Journal of Applied Psychology, Vol.86, No.1, pp.114-121.

Luo, Y. and Child, J. (2015), "A Composition-Based View of Firm Growth", Management and Organization Review, Vol.11, No.03, pp.379-411.

Mamun, A. and Fazal, S.A., (2018), "Effect of entrepreneurial orientation on competency and micro-enterprise performance", Asia Pacific Journal of Innovation and Entrepreneurship, Vol.12, No.3, pp.379-398.

Mamun, A.A., Nawi, N.B.C., Permarupan, P.Y. and Muniady, R., (2018), "Sources of competitive advantage for Malaysian micro-enterprises", Journal of Entrepreneurship in Emerging Economies, Vol.10, No.2, pp 191-126.

Man, W. y. T. (2001). Entrepreneurial Competencies and the Performance of Small and Medium Enterprises in the Hong Kong Services Sector (unpublished doctoral dissertation). The Hong Kong Polytechnic University.

Man, T. W., Lau, T. and Chan, K. (2002), "The Competitiveness of Small and Medium Enterprises: A conceptualisation with Focus on Entrepreneurial Competencies", Journal of Business Venturing, Vol.17, No.2, pp.123-142.

McKeever, E., Anderson, A. and Jack, S., (2014), "Social embeddedness in entrepreneurship research: the importance of context and community", Handbook of research on small business and entrepreneurship, Vol.222.

Mickiewicz, T., Hart, M., Nyakudya, F., and Theodorakopoulos, N. (2019), "Ethnic pluralism, immigration and entrepreneurship", Regional Studies, Vol.53, No.1, pp.80-94. 
Mohammed, K., Ibrahim, H.I. and Shah, K.A.M. (2017), "Empirical evidence of entrepreneurial competencies and firm performance: a study of women entrepreneurs of Nigeria", International Journal of Entrepreneurial Knowledge, Vol. 5 No. 1, pp. 49-61.

Mohsin, A.M.B.A., Halim, H.A., Ahmad, A.H., (2015), “Assessing the Role of Entrepreneurial Competencies on Innovation Performance: A Partial Least Squares (PLS) Approach", Proceedings of 11th Asian Academy of Management International Conference (AAMC 2015), pp.1436-1445.

Nakhata, C. (2018), “The relationships between human capital, entrepreneurial competencies and career success of SME entrepreneurs in Thailand", AU Journal of Management, Vol.5, No.1, pp.1726.

Namusonge, M. (2014), "Linking Competencies with Strategies: The Case of Small and MediumSized Exporting Firms in Kenya", International Journal of Social Sciences and Entrepreneurship, Vol.1, No.11, pp.1-21.

Ng, H. S. and Kee, D. M. H. (2013), "Effect of Entrepreneurial Competencies on Firm Performance under the Influence of Organisational Culture", Life Science Journal, Vol.10, No.4, pp.2459-2466.

Orme, G. and Ashton, C. (2003), "Ethics-a Foundation Competency", Industrial and Commercial Training, Vol.35, No.5, pp.184-190.

Osagie, E. R., Wesselink, R., Blok, V., Lans, T., and Mulder, M. (2016), "Individual competencies for corporate social responsibility: A literature and practice perspective", Journal of Business Ethics, Vol.135, No.2, pp.233-252.

Parnell, J. A., Lester, D. L. and Menefee, M. L. (2000), "Strategy as a Response to Organisational Uncertainty: An Alternative Perspective on the Strategy-Performance Relationship", Management Decision, Vol.38, No.8, pp.520-530.

Quagrainie, F. A. (2018), "Family values and practices promoting entrepreneurial competencies among Ghanaian women", International Journal of Entrepreneurship and Small Business, Vol.33, No.2, pp.202-219.

Rahman, S. A., Amran, A., Ahmad, N. H. and Taghizadeh, S. K. (2014), "Prospective Entrepreneurial Competencies to Ensure Subjective Wellbeing of the Entrepreneurs at the Base of Pyramid", In Proceedings Book of ICBSSS, 2014, Malaysia (pp. 56-64).

Ramayah, T., Yeap, J. A., Ahmad, N. H., Halim, H. A., and Rahman, S. A. (2017), "Testing a confirmatory model of facebook usage in smartpls using consistent PLS", International Journal of Business and Innovation, Vol.3, No.2, pp.1-14.

Ramayah, T., Cheah, J., Chuah, F., Ting, H., Memon, M.A., (2018), "Partial Least Squares Structural Equation Modelling (PLS-SEM) using SMARTPLS 3.0: An Updated and Practical Guide to Statistical Analysis", (2nd edt), Pearson: Malaysia.

Rahman, S. A., Ahmad, N. A., Taghizadeh, S. K., (2015a), "Entrepreneurial Competencies of the BoP Entrepreneurs in Achieving Business Success: A Study on the Mom and Pop Shops in Urban Cities of Bangladesh", Proceedings of 11th Asian Academy of Management International Conference (AAMC 2015), pp.1552-1563.

Rasoolimanesh, S. M., Roldán, J. L., Jaafar, M. and Ramayah, T. (2016), "Factors Influencing Residents' Perceptions toward Tourism Development Differences Across Rural and Urban World Heritage Sites", Journal of Travel Research, Vol.26, No.1, pp.28-38. 
Redding, G., (2008), "Separating culture from institutions: The use of semantic spaces as a conceptual domain and the case of China", Management and Organization Review, Vol.4, No.2, pp.257-289.

Rowe, C. (1995), "Clarifying the Use of Competence and Competency Models in Recruitment, Assessment and Staff Development", Industrial and Commercial Training, Vol.27, No.11, pp.12-17.

Sanchez-Famoso, V., Pittino, D., Chirico, F., Maseda, A., and Iturralde, T. (2019), "Social Capital and Innovation in Family Firms. The Moderating Roles of Family Control and Generational Involvement", Scandinavian Journal of Management.

SME Corporation Malaysia (2018), "SME definitions", available at: www.smecorp.gov.my/index.php/en/policies/2015-12-21-09-09-49/sme-definition (accessed 20 October 2018).

Stephen, I. A., Ayodele, O. M., and Oluremi, O. A. (2017), "Enhancing the Performance of Agro Based SMES: The Role of Entrepreneurship Competencies", Covenant Journal of Entrepreneurship, Vol.1, No.1.

Stephen, I.A., Ayodele, O.M., Oluremi, O.A. and Ifeoma, N.C. (2017), "Enhancing the performance of agro-based SMES: the role of entrepreneurship competencies", Covenant Journal of Entrepreneurship, Vol. 1 No. 1, pp. 44-51.

Storey, D.J., (2016), Understanding the small business sector. Routledge.

Stuart, R. W. and Abetti, P. A. (1990), "Impact of Entrepreneurial and Management Experience on Early Performance", Journal of Business Venturing, Vol.5, No.3, pp.151-162.

Suhaimi, N. H. B. M., Al Mamun, A., Zainol, N. R., and Nawi, N. (2018), "The Moderating Effect of a Supportive Environment Toward the Relationship of Entrepreneurial Competencies and the Performance of Informal Women Entrepreneurs in Kelantan, Malaysia", The Journal of Developing Areas, Vol.52, No.1, pp.251-259.

Tehseen, S., Ramayah, T., and Sajilan, S. (2017), "Testing and controlling for common method variance: A review of available methods", Journal of Management Sciences, Vol. 4, No 2, pp.142-168.

Tehseen, S. and Ramayah, T. (2015), "Entrepreneurial Competencies and SMEs Business Success: The Contingent Role of External Integration", Mediterranean Journal of Social Sciences, Vol.6, No.1, pp.50-61.

Tehseen, S., Ahmed, F. U., Qureshi, Z. H., and Uddin, M. J. (2019), "Entrepreneurial competencies and SMEs' growth: the mediating role of network competenc", Asia-Pacific Journal of Business Administration, Vol.11, No.1, pp.2-29.

Terpstra-Tong, J. L., Terpstra, R. H. and Tee, D. D. (2014), "Convergence and Divergence of Individual-Level Values: A Study of Malaysian Managers", Asian Journal of Social Psychology, Vol.17, No.3, pp.236-243.

Tsai, W. M. H., MacMillan, I. C. and Low, M. B. (1991), "Effects of Strategy and Environment on Corporate Venture Success in Industrial Markets", Journal of Business Venturing, Vol.6, No.1, pp.9-28.

Tunberg, M. and Anderson, A.R, 2020, Growing a small firm; experiences and managing difficult processes, International Journal of Entrepreneurship and Management, forthcoming

Umar, A., and Ngah, R. (2017), "The Relationship of Entrepreneurial Competencies and Business Success of Malaysian SMEs: The Mediating Role of Innovation and Brand Equity", World 
Academy of Science, Engineering and Technology, International Journal of Economics and Management Engineering, Vol.4, No.6.

Wijaya, Y. (2008), "The Prospect of Familism in the Global Era: A Study on the Recent Development of the Ethnic-Chinese Business, with Particular Attention to the Indonesian Context", Journal of Business Ethics, Vol.79, No.3, pp.311-317.

Wiklund, J. (1999), "The Sustainability of the Entrepreneurial Orientation-Performance Relationship", Entrepreneurship: Theory and Practise, Vol.24, No.1, pp.37-37.

Wiklund, J. (2006), "The Sustainability of the Entrepreneurial Orientation-Performance Relationship", Entrepreneurship and the Growth of Firms, Vol.7, No.3, pp.141-155.

Wu, L. and Li, J., (2011), "Perceived value of entrepreneurship: A study of the cognitive process of entrepreneurial career decision", Journal of Chinese Entrepreneurship, Vol.3, No2, pp.134-146.

Yusuff, Y.Z., Bakar, A.A. and Ahmad (2016), "Entrepreneurial competencies and business performance among women entrepreneurs", Proceeding: The 2nd International Conference on Business Management (ICBM), Vol 1, No. 1, 978-967-13903 -5 -1.

Zahra, S. A. (1991), "Predictors and Financial Outcomes of Corporate Entrepreneurship: An Exploratory Study", Journal of Business Venturing, Vol.6, No.4, pp.259-285.

Zeiders, K. H., Updegraff, K. A., Umaña-Taylor, A. J., McHale, S. M. and Padilla, J. (2016), "Familism Values, Family Time and Mexican-Origin Young Adults' Depressive Symptoms", Journal of Marriage and Family, Vol.78, No.1, pp.91-106.

Zhang, X., (2012), The Impact of Entrepreneurial Learning on Entrepreneurial Performance: The Mediating Role of Entrepreneurial Competencies. In Advances in Electrical Engineering and Automation (pp. 229-234). Springer, Berlin, Heidelberg.

Table I. Items' Measures and Sources

\begin{tabular}{|c|c|c|c|}
\hline Variables & Items & Number of Items & Sources \\
\hline \multirow{5}{*}{$\begin{array}{l}\text { Strategic } \\
\text { Competency (SC) }\end{array}$} & $\begin{array}{l}\text { SC1: I always monitor progress towards } \\
\text { strategic goals. }\end{array}$ & 5 & Ahmad (2007); Man (2001) \\
\hline & $\begin{array}{l}\text { SC2: I prioritize work in alignment with } \\
\text { business goals }\end{array}$ & & \\
\hline & $\begin{array}{l}\text { SC3: I usually assess and link short term, } \\
\text { day to day tasks in the context of long } \\
\text { term direction. }\end{array}$ & & \\
\hline & $\begin{array}{l}\text { SC4: I evaluate results against strategic } \\
\text { goals. }\end{array}$ & & \\
\hline & $\begin{array}{l}\text { SC5: I align current actions with strategic } \\
\text { goals. }\end{array}$ & & \\
\hline \multirow{3}{*}{$\begin{array}{l}\text { Opportunity } \\
\text { Competency (OC) }\end{array}$} & $\begin{array}{l}\text { OC1: I avail high quality business } \\
\text { opportunities. }\end{array}$ & 3 & Ahmad (2007); Man (2001) \\
\hline & $\begin{array}{l}\text { OC2: I take an idea or concept and make } \\
\text { something out of it. }\end{array}$ & & \\
\hline & $\begin{array}{l}\text { OC3: I scan the environment to explore } \\
\text { opportunities. }\end{array}$ & & \\
\hline \multirow{4}{*}{$\begin{array}{l}\text { Learning } \\
\text { Competency (LC) }\end{array}$} & LC1: I learn proactively. & 3 & Ahmad (2007); Man (2001) \\
\hline & LC2: I learn as much as I can in my field. & & \\
\hline & LC3: I keep up to date in my field. & & \\
\hline & $\begin{array}{l}\text { LC4: I apply learned skills and knowledge } \\
\text { to actual practice. }\end{array}$ & & \\
\hline
\end{tabular}




\begin{tabular}{|c|c|c|c|}
\hline \multirow{3}{*}{$\begin{array}{l}\text { Ethical } \\
\text { Competency (EC) }\end{array}$} & $\begin{array}{l}\text { EC1: I engage in fair, open and honest } \\
\text { marketing practices. }\end{array}$ & 3 & Ahmad (2007) \\
\hline & $\begin{array}{l}\mathrm{EC} 2 \text { : I try to be transparent and honest in } \\
\text { business dealings. }\end{array}$ & & \\
\hline & $\begin{array}{l}\text { EC3: I strive to be committed in offering } \\
\text { goods and services at fair prices. }\end{array}$ & & \\
\hline \multirow{3}{*}{$\begin{array}{l}\text { Personal } \\
\text { Competency (PC) }\end{array}$} & PC1: I maintain a positive attitude. & 3 & Ahmad (2007); Man (2001 \\
\hline & PC2: I priorities tasks to manage my time. & & \\
\hline & $\begin{array}{l}\text { PC3: I recognize and work on my own } \\
\text { weaknesses. }\end{array}$ & & \\
\hline \multirow[t]{3}{*}{ Familism (FC) } & $\begin{array}{l}\text { FC1: I cooperate with and help others } \\
\text { (especially with close associates) in } \\
\text { business. }\end{array}$ & 3 & Ahmad (2007) \\
\hline & $\begin{array}{l}\text { FC2: I identify and seek help from } \\
\text { employees I trust. }\end{array}$ & & \\
\hline & $\begin{array}{l}\text { FC3: I build a foundation to next } \\
\text { generation to continue the business. }\end{array}$ & & \\
\hline \multirow[t]{5}{*}{$\begin{array}{c}\text { Conceptual } \\
\text { Competency }(\mathrm{CC})\end{array}$} & $\begin{array}{l}\mathrm{CC} 1 \text { : I understand the broader business } \\
\text { implications of ideas, issues and } \\
\text { observations. }\end{array}$ & 5 & Ahmad (2007); Man (2001) \\
\hline & $\begin{array}{l}\text { CC2: I translate ideas, issues, and } \\
\text { observations into the business context. }\end{array}$ & & \\
\hline & $\begin{array}{l}\text { CC3: I am well planned in making } \\
\text { decisions. }\end{array}$ & & \\
\hline & CC4: I take reasonable job-related risks. & & \\
\hline & $\begin{array}{l}\text { CC5: I remain proactive and responsive to } \\
\text { changes. }\end{array}$ & & \\
\hline \multirow{4}{*}{$\begin{array}{l}\text { Business Growth } \\
\text { (BG) }\end{array}$} & BG1: I am satisfied with growth of sales. & 4 & Brinckman (2008); Ahmad (2007); and \\
\hline & $\begin{array}{l}\text { BG2: I am satisfied with growth in market } \\
\text { share. }\end{array}$ & & Wiklund (1999); Chandler \& Hanks (1993) \\
\hline & $\begin{array}{l}\text { BG3: I am satisfied with growth of cash } \\
\text { flow. }\end{array}$ & & \\
\hline & $\begin{array}{l}\text { BG4: I am satisfied with annual } \\
\text { employment growth. }\end{array}$ & & \\
\hline
\end{tabular}

Table II. Demographic Profile of Respondents

\begin{tabular}{ccccccc}
\hline Categories & \multicolumn{2}{c}{ Chinese Sample $(\mathbf{N}=\mathbf{2 0 0})$} & \multicolumn{2}{c}{ Malay Sample $(\mathbf{N}=\mathbf{2 0 0})$} & \multicolumn{2}{c}{ Indian Sample $(\mathbf{N}=\mathbf{2 0 0})$} \\
\hline Age & Frequency & Percentages & Frequency & Percentages & Frequency & Percentages \\
$\mathbf{2 1 - 3 0}$ & 11 & 5.5 & 12 & 6.0 & 18 & 9.0 \\
$\mathbf{3 1 - 4 0}$ & 64 & 32.0 & 119 & 59.5 & 48 & 24.0 \\
$\mathbf{4 1 - 5 0}$ & 109 & 54.5 & 66 & 33.0 & 120 & 60.0 \\
$\mathbf{5 1 - 6 0}$ & 15 & 7.5 & 3 & 1.5 & 14 & 7.0 \\
$\mathbf{6 1}$ an above & 1 & 0.5 & 0 & 0 & 0 & 0 \\
Gender & & & & & & \\
Female & 124.0 & 62.0 & 54 & 27.0 & 98 & 49.0 \\
Male & 76 & 38.0 & 146 & 73.0 & 102 & 51.0 \\
Race/ Ethnicity & & & & & & \\
Malay & 0 & 0 & 200 & 100 & 0 & 0 \\
\hline
\end{tabular}




\begin{tabular}{|c|c|c|c|c|c|c|}
\hline Chinese & 200 & 100 & 0 & 0 & 0 & 0 \\
\hline Indian & 0 & 0 & 0 & 0 & 200 & 100 \\
\hline \multicolumn{7}{|l|}{ Marital Status } \\
\hline Single & 57 & 28.5 & 19 & 9.5 & 35 & 17.5 \\
\hline Married & 116 & 58.0 & 126 & 63.0 & 147 & 73.5 \\
\hline Divorced & 20 & 10.0 & 45 & 22.5 & 15 & 7.5 \\
\hline $\begin{array}{l}\text { Widowed } \\
\text { Religious }\end{array}$ & 7 & 3.5 & 10 & 5.0 & 3 & 1.5 \\
\hline \multicolumn{7}{|l|}{ Background } \\
\hline Muslim & 0 & 0 & 200 & 100 & 38 & 19.0 \\
\hline Hindu & 0 & 0 & 0 & 0 & 101 & 50.5 \\
\hline Buddhist & 84 & 42.0 & 0 & 0 & 0 & 0 \\
\hline $\begin{array}{c}\text { Christian } \\
\text { Highest }\end{array}$ & 116 & 58.0 & 0 & 0 & 61 & 30.5 \\
\hline \multicolumn{7}{|l|}{ Education } \\
\hline $\begin{array}{c}\text { Bachelor } \\
\text { degree }\end{array}$ & 116 & 58.0 & 143 & $\begin{array}{c}1.0 \\
71.5\end{array}$ & $\begin{array}{l}10 \\
125\end{array}$ & 62.5 \\
\hline Master degree & 47 & 23.5 & 49 & 24.5 & 48 & 24.0 \\
\hline PhD & 0 & 0 & 6 & 3.0 & 17 & 8.5 \\
\hline \multicolumn{7}{|l|}{$\begin{array}{c}\text { Family } \\
\text { Background }\end{array}$} \\
\hline Middle class & 59 & 29.5 & 118 & 59.0 & 75 & 37.5 \\
\hline $\begin{array}{l}\text { Upper middle } \\
\text { class }\end{array}$ & 141 & 70.5 & 82 & 41.0 & 125 & 62.5 \\
\hline $\begin{array}{c}\text { Lower middle } \\
\text { class }\end{array}$ & 0 & 0 & 0 & 0 & 0 & 0 \\
\hline
\end{tabular}

Table III. Demographic Profile of Firms

\begin{tabular}{|c|c|c|c|c|c|c|}
\hline \multirow[t]{2}{*}{ Categories } & \multicolumn{2}{|c|}{ Chinese Sample $(\mathrm{N}=200)$} & \multicolumn{2}{|c|}{ Malay Sample $(\mathrm{N}=\mathbf{2 0 0})$} & \multicolumn{2}{|c|}{ Indian Sample $(\mathrm{N}=\mathbf{2 0 0})$} \\
\hline & Frequency & Percentages & Frequency & Percentages & Frequency & Percentages \\
\hline Selangor & 58 & 29.0 & 43 & 21.5 & 48 & 24.0 \\
\hline Kuala Lumpur & 60 & 30.0 & 59 & 29.5 & 52 & 26.0 \\
\hline Putra Jaya & 10 & 5.0 & 4 & 2.0 & 6 & 3.0 \\
\hline Perlis & 8 & 4.0 & 4 & 2.0 & 12 & 6.0 \\
\hline Kedah & 10 & 5.0 & 6 & 3.0 & 6 & 3.0 \\
\hline Penang & 10 & 5.0 & 6 & 3.0 & 12 & 6.0 \\
\hline Perak & 6 & 3.0 & 8 & 4.0 & 12 & 6.0 \\
\hline Kelantan & 4 & 2.0 & 12 & 6.0 & 6 & 3.0 \\
\hline Terengganu & 4 & 2.0 & 12 & 6.0 & 8 & 4.0 \\
\hline Pahang & 6 & 3.0 & 10 & 5.0 & 4 & 2.0 \\
\hline Malacca & 6 & 3.0 & 14 & 7.0 & 8 & 4.0 \\
\hline Johor & 10 & 5.0 & 10 & 5.0 & 12 & 6.0 \\
\hline Negeri Sembilan & 8 & 4.0 & 12 & 6.0 & 14 & 7.0 \\
\hline \multicolumn{7}{|l|}{ No of employees } \\
\hline $5-30$ & 166 & 83.0 & 163 & 81.5 & 169 & 84.5 \\
\hline $30-75$ & 34 & 17.0 & 37 & 18.5 & 31 & 15.5 \\
\hline \multicolumn{7}{|l|}{$\begin{array}{l}\text { Prior Working } \\
\text { Experiences }\end{array}$} \\
\hline No experiences & 7 & 3.5 & 27 & 13.5 & 4 & 2.0 \\
\hline 1-2 years & 26 & 13.0 & 86 & 43.0 & 49 & 24.5 \\
\hline 3-4 years & 60 & 30.0 & 77 & 38.5 & 67 & 33.5 \\
\hline 5-7 years & 91 & 45.5 & 8 & 4.0 & 72 & 36.0 \\
\hline 7-10 years & 12 & 6.0 & 2 & 1.0 & 8 & 4.0 \\
\hline $11-15$ years & 4 & 2.0 & 0 & 0 & 0 & 0 \\
\hline \multicolumn{7}{|l|}{$\begin{array}{l}\text { Position in } \\
\text { Company }\end{array}$} \\
\hline Business Owner & 184 & 92.0 & 162 & 81.0 & 165 & 82.5 \\
\hline
\end{tabular}




\begin{tabular}{|c|c|c|c|c|c|c|}
\hline Business Partner & 16 & 8.0 & 38 & 19.0 & 35 & 17.5 \\
\hline \multicolumn{7}{|l|}{$\begin{array}{c}\text { Years of Company } \\
\text { Start Up }\end{array}$} \\
\hline $3-5$ & 20 & 10.0 & 7 & 3.5 & 10 & 5.0 \\
\hline $6-10$ & 92 & 46.0 & 123 & 61.5 & 69 & 34.5 \\
\hline $11-20$ & 88 & 44.0 & 70 & 35.0 & 121 & 60.5 \\
\hline \multicolumn{7}{|l|}{$\begin{array}{c}\text { Annual Sales } \\
\text { Turnover }\end{array}$} \\
\hline $\begin{array}{l}\text { RM } 300,000 \text { to less } \\
\text { than RM } 3 \text { million }\end{array}$ & 166 & 83.0 & 163 & 81.5 & 169 & 84.5 \\
\hline $\begin{array}{c}\text { RM } 3 \text { million to not } \\
\text { exceeding RM } 20 \\
\text { million }\end{array}$ & 34 & 17.0 & 37 & 18.5 & 31 & 15.5 \\
\hline \multicolumn{7}{|l|}{ Business Category } \\
\hline Wholesale & 97 & 48.5 & 52 & 26.0 & 83 & 41.5 \\
\hline Retail & 103 & 51.5 & 148 & 74.0 & 117 & 58.5 \\
\hline \multicolumn{7}{|l|}{$\begin{array}{l}\text { Wholesale/Retail } \\
\text { Format }\end{array}$} \\
\hline $\begin{array}{l}\text { Pharmaceutical, } \\
\text { medical, and } \\
\text { orthopaedic goods }\end{array}$ & 4 & 2.0 & 0 & 0 & 2 & 1.0 \\
\hline $\begin{array}{l}\text { Textile and } \\
\text { Clothing }\end{array}$ & 4 & 2.0 & 36 & 18.0 & 18 & 9.0 \\
\hline Tudung & & & 42 & 21.0 & 8 & 4.0 \\
\hline $\begin{array}{l}\text { Footwear and } \\
\text { leather goods }\end{array}$ & 8 & 4.0 & 0 & 0 & 3 & 1.5 \\
\hline $\begin{array}{l}\text { Household } \\
\text { appliances and } \\
\text { equipment }\end{array}$ & 10 & 5.0 & 4 & 2.0 & 7 & 3.5 \\
\hline $\begin{array}{l}\text { Hardware, paint } \\
\text { and glass }\end{array}$ & 2 & 1.0 & 7 & 3.5 & 9 & 4.5 \\
\hline $\begin{array}{l}\text { Sports and } \\
\text { recreational goods }\end{array}$ & 9 & 4.5 & 1 & 0.5 & 10 & 5.0 \\
\hline $\begin{array}{l}\text { Boutique, Salon, } \\
\text { and Spa }\end{array}$ & 7 & 3.5 & 3 & 1.5 & 11 & 5.5 \\
\hline Gifts and crafts & 8 & 4.0 & 4 & 2.0 & 10 & 5.0 \\
\hline Watches & 12 & 6.0 & 12 & 6.0 & 6 & 3.0 \\
\hline Carpets & 16 & 8.0 & 16 & 8.0 & 17 & 8.5 \\
\hline Perfumes & 26 & 13.0 & 27 & 13.5 & 15 & 7.5 \\
\hline Furniture & 26 & 13.0 & 9 & 4.5 & 11 & 5.5 \\
\hline Toys & 21 & 10.5 & 6 & 3.0 & 5 & 2.5 \\
\hline Books & 12 & 6.0 & 20 & 10.0 & 18 & 9.0 \\
\hline $\begin{array}{l}\text { Interior } \\
\text { decorators }\end{array}$ & 13 & 6.5 & 7 & 3.5 & 16 & 8.0 \\
\hline $\begin{array}{l}\text { Towel and bed } \\
\text { sheets }\end{array}$ & 10 & 5.0 & 3 & 1.5 & 9 & 4.5 \\
\hline Gold and diamond & 12 & 6.0 & 3 & 1.5 & 25 & 12.5 \\
\hline $\begin{array}{l}\text { Ownership } \\
\text { Structure }\end{array}$ & & & & & & \\
\hline $\begin{array}{l}\text { Sole } \\
\text { Proprietorship }\end{array}$ & 12 & 6.0 & 0 & 0 & 8 & 4.0 \\
\hline Partnership & 73 & 36.5 & 72 & 36.0 & 63 & 31.5 \\
\hline $\begin{array}{l}\text { Private Limited } \\
\text { Company }\end{array}$ & 115 & 57.5 & 128 & 64.0 & 129 & 64.5 \\
\hline
\end{tabular}


Table IV.

Assessment of Reliability and Validity

\begin{tabular}{|c|c|c|c|c|c|c|c|c|c|c|c|c|}
\hline \multirow[b]{2}{*}{ Constructs } & \multicolumn{4}{|c|}{ Chinese Sample $(\mathrm{N}=200)$} & \multicolumn{4}{|c|}{ Malay Sample $(N=200)$} & \multicolumn{4}{|c|}{ Indian Sample $(\mathrm{N}=\mathbf{2 0 0})$} \\
\hline & $\begin{array}{l}\text { Cronbach's } \\
\text { Alpha }\end{array}$ & rho_A & $\begin{array}{l}\text { Composite } \\
\text { Reliability }\end{array}$ & $\begin{array}{c}\text { Average } \\
\text { Variance } \\
\text { Extracted } \\
\text { (AVE) }\end{array}$ & $\begin{array}{l}\text { Cronbach's } \\
\text { Alpha }\end{array}$ & rho_A & $\begin{array}{l}\text { Composite } \\
\text { Reliability }\end{array}$ & $\begin{array}{l}\text { Average } \\
\text { Variance } \\
\text { Extracted } \\
\text { (AVE) }\end{array}$ & $\begin{array}{l}\text { Cronbach's } \\
\text { Alpha }\end{array}$ & rho_A & $\begin{array}{l}\text { Composite } \\
\text { Reliability }\end{array}$ & $\begin{array}{l}\text { Average } \\
\text { Variance } \\
\text { Extracted } \\
\text { (AVE) }\end{array}$ \\
\hline SC & 0.690 & 0.694 & 0.812 & 0.521 & 0.770 & 0.777 & 0.851 & 0.588 & 0.770 & 0.777 & 0.851 & 0.588 \\
\hline OC & 0.680 & 0.732 & 0.774 & 0.553 & 0.680 & 0.711 & 0.768 & 0.548 & 0.680 & 0.722 & 0.771 & 0.550 \\
\hline $\mathbf{L C}$ & 0.850 & 0.865 & 0.900 & 0.695 & 0.850 & 0.865 & 0.900 & 0.695 & 0.850 & 0.866 & 0.900 & 0.695 \\
\hline EC & 0.763 & 1.723 & 0.829 & 0.625 & 0.782 & 0.783 & 0.873 & 0.697 & 0.526 & 0.546 & 0.761 & 0.518 \\
\hline $\mathbf{P C}$ & 0.659 & 0.703 & 0.804 & 0.580 & 0.659 & 0.706 & 0.803 & 0.579 & 0.659 & 0.707 & 0.803 & 0.579 \\
\hline FC & 0.760 & 0.791 & 0.862 & 0.676 & 0.760 & 0.787 & 0.862 & 0.676 & 0.760 & 0.789 & 0.862 & 0.676 \\
\hline $\mathrm{CC}$ & 0.811 & 0.812 & 0.877 & 0.641 & 0.811 & 0.812 & 0.877 & 0.641 & 0.811 & 0.812 & 0.877 & 0.641 \\
\hline BG & 0.806 & 0.816 & 0.873 & 0.632 & 0.806 & 0.814 & 0.873 & 0.633 & 0.806 & 0.812 & 0.873 & 0.633 \\
\hline
\end{tabular}


Table V.

HTMT Criterion

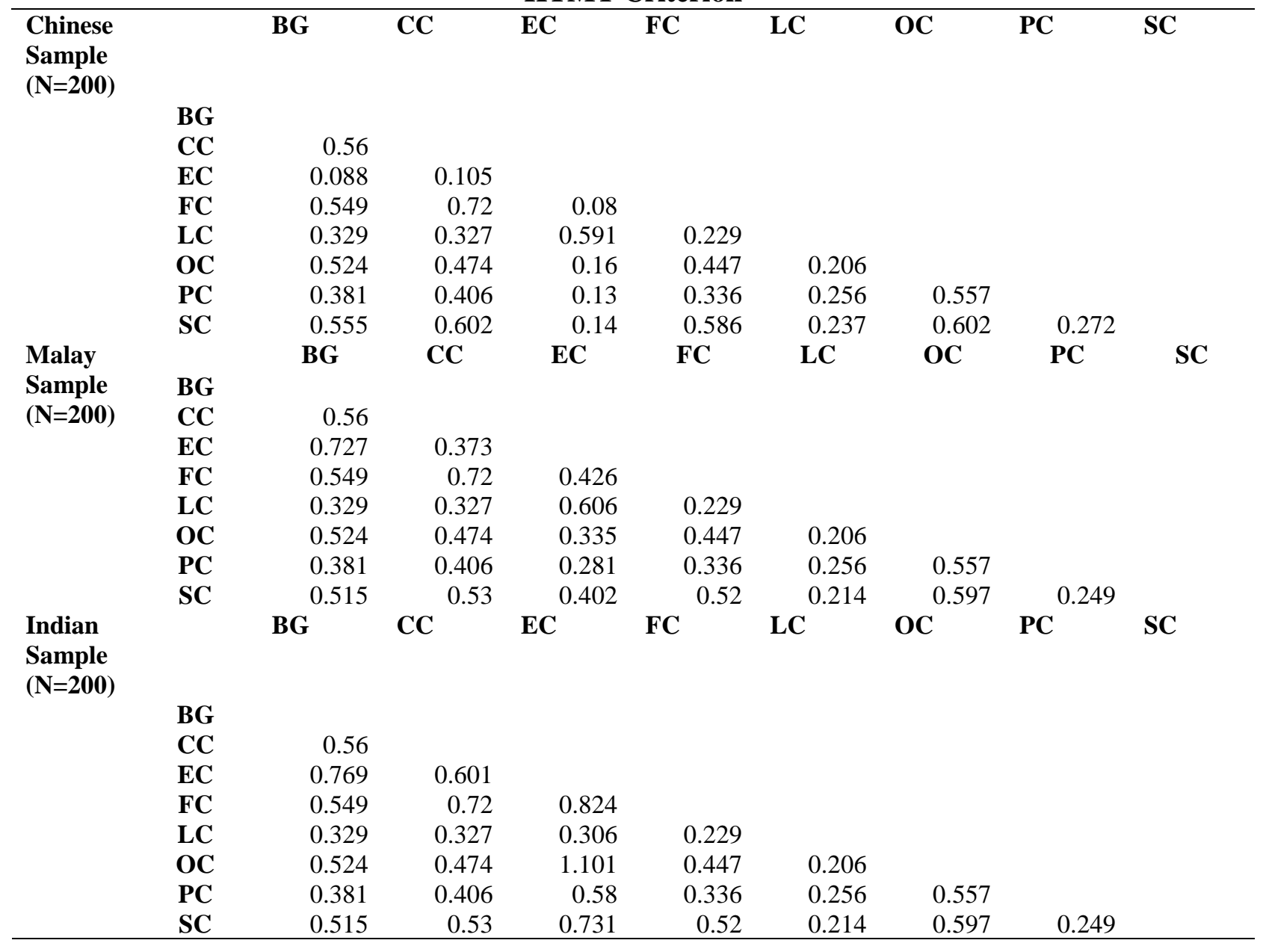


Figure 1:

\section{Conceptual Framework}

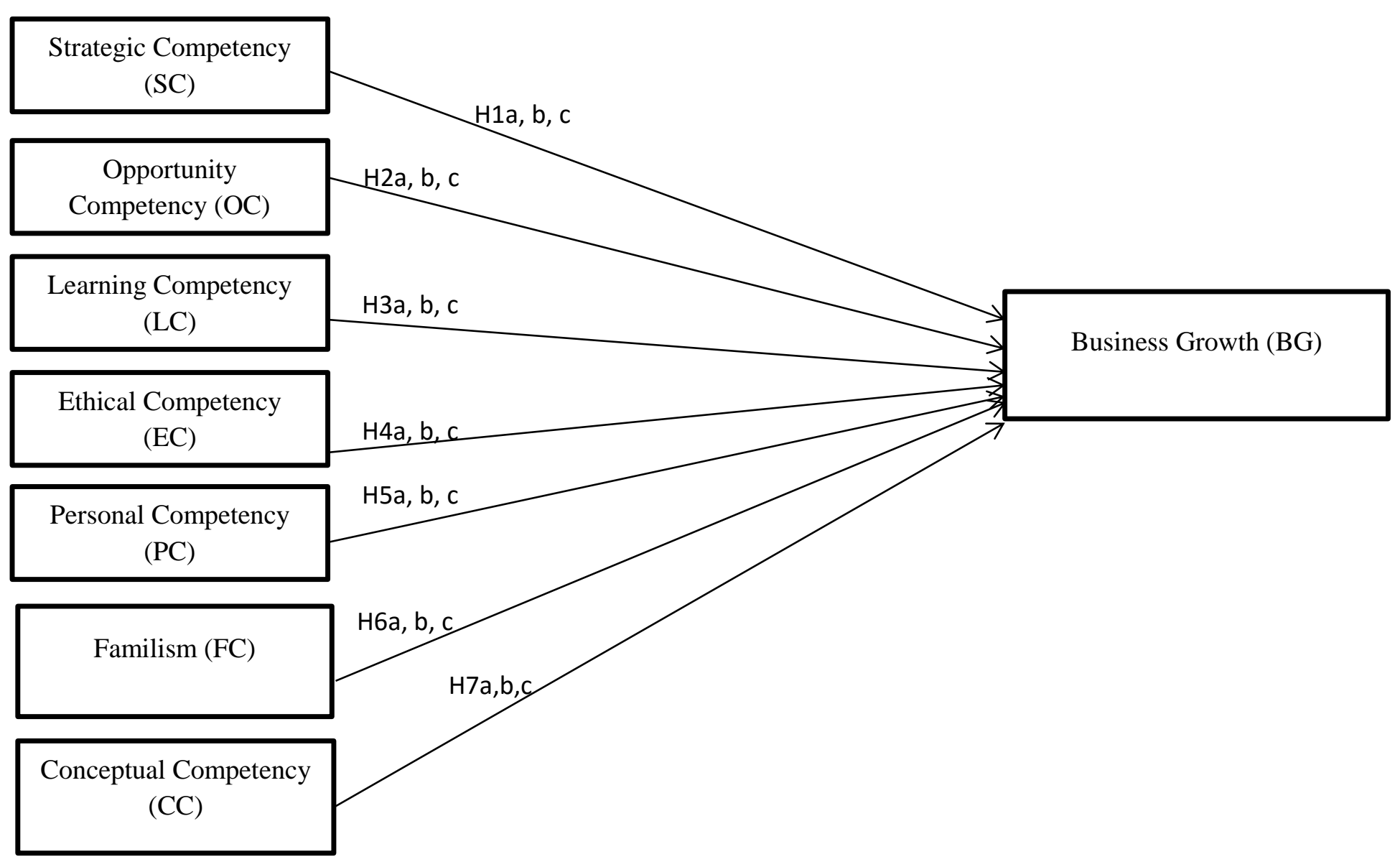


Table V1.

Testing of Hypotheses

\begin{tabular}{|c|c|c|c|c|c|c|c|c|c|c|c|c|}
\hline \multirow[b]{2}{*}{ Hypotheses } & \multicolumn{4}{|c|}{ Chinese Sample $(\mathrm{N}=150)$} & \multicolumn{4}{|c|}{ Malay Sample (N=150) } & \multicolumn{4}{|c|}{ Indian Sample (N=150) } \\
\hline & Beta & $\begin{array}{l}\text { Standard } \\
\text { Deviation } \\
\text { (STDEV) }\end{array}$ & $\begin{array}{c}\mathbf{T} \\
\text { Statistics }\end{array}$ & $f^{2}$ & Beta & $\begin{array}{l}\text { Standard } \\
\text { Deviation } \\
\text { (STDEV) }\end{array}$ & $\begin{array}{c}\mathbf{T} \\
\text { Statistics }\end{array}$ & $f^{2}$ & Beta & $\begin{array}{l}\text { Standard } \\
\text { Deviation } \\
\text { (STDEV) }\end{array}$ & $\begin{array}{c}\mathbf{T} \\
\text { Statistics }\end{array}$ & $f^{2}$ \\
\hline H1: SC-> BG & 0.151 & 0.08 & $* 1.873$ & 0.026 & 0.099 & 0.066 & 1.492 & 0.013 & 0.148 & 0.077 & *1.928 & 0.024 \\
\hline H2: OC-> BG & 0.202 & 0.105 & *1.918 & 0.045 & 0.165 & 0.101 & 1.634 & 0.035 & 0.085 & 0.118 & 0.724 & 0.005 \\
\hline H3: LC-> BG & 0.146 & 0.066 & $* * 2.212$ & 0.023 & -0.062 & 0.052 & 1.193 & 0.005 & 0.122 & 0.06 & $* * 2.029$ & 0.022 \\
\hline H4: EC-> BG & -0.041 & 0.084 & 0.486 & 0.002 & 0.431 & 0.066 & $* * * 6.489$ & 0.238 & 0.183 & 0.1 & *1.826 & 0.022 \\
\hline H5: PC-> BG & 0.129 & 0.068 & *1.913 & 0.023 & 0.094 & 0.072 & 1.293 & 0.015 & 0.123 & 0.063 & *1.938 & 0.021 \\
\hline H6: FC-> BG & 0.174 & 0.062 & $* * * 2.79$ & 0.030 & 0.105 & 0.059 & *1.757 & 0.013 & 0.126 & 0.071 & *1.771 & 0.014 \\
\hline H7: CC-> BG & 0.137 & 0.078 & $* 1.764$ & 0.017 & 0.147 & 0.071 & $* * 2.088$ & 0.025 & 0.146 & 0.075 & *1.935 & 0.020 \\
\hline
\end{tabular}

Note: Critical t values

*1.65 (significance level $=10 \%$ )

$* * * 2.57$ (significance level= $1 \%$ ). 
Table V11.

Multi-Group Analysis

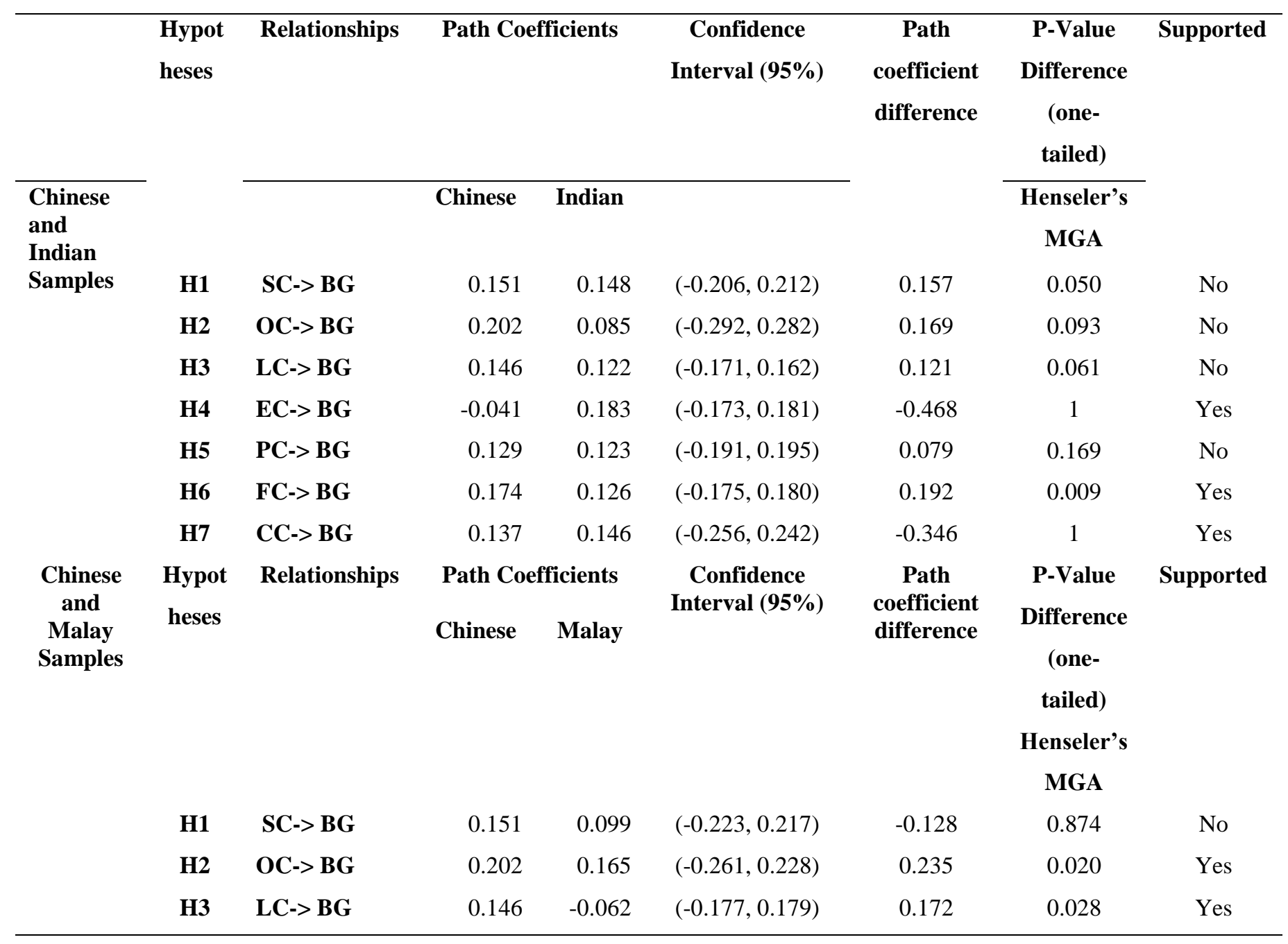




\begin{tabular}{|c|c|c|c|c|c|c|c|c|}
\hline \multirow{14}{*}{$\begin{array}{c}\text { Indian } \\
\text { and } \\
\text { Malay } \\
\text { Samples }\end{array}$} & H4 & EC-> BG & -0.041 & 0.431 & $(-0.70,0.154)$ & -0.102 & 0.820 & No \\
\hline & H5 & PC-> BG & 0.129 & 0.094 & $(-0.180,0.192)$ & -0.062 & 0.763 & No \\
\hline & H6 & FC-> BG & 0.174 & 0.105 & $(-0.210,0.201)$ & 0.179 & 0.013 & Yes \\
\hline & H7 & CC-> BG & 0.137 & 0.147 & $(-0.227,0.234)$ & -0.274 & 0.989 & Yes \\
\hline & \multirow[t]{3}{*}{ heses } & Relationships & \multicolumn{2}{|c|}{ Path Coefficients } & \multirow[t]{3}{*}{$\begin{array}{l}\text { Confidence } \\
\text { Interval (95\%) }\end{array}$} & \multirow[t]{3}{*}{$\begin{array}{c}\text { Path } \\
\text { coefficient } \\
\text { difference }\end{array}$} & $\begin{array}{c}\text { P-Value } \\
\text { Difference } \\
\text { (one- } \\
\text { tailed) }\end{array}$ & Supported \\
\hline & & & Indian & Malay & & & Henseler's & \\
\hline & & & & & & & MGA & \\
\hline & H1 & SC-> BG & 0.148 & 0.099 & $(-0.204,0.231)$ & -0.285 & 0.998 & Yes \\
\hline & $\mathbf{H} 2$ & OC-> BG & 0.085 & 0.165 & $(-0.206,0.207)$ & 0.066 & 0.252 & No \\
\hline & H3 & LC-> BG & 0.122 & -0.062 & $(-0.137,0.135)$ & 0.051 & 0.240 & No \\
\hline & H4 & EC-> BG & 0.183 & 0.431 & $(-0.200,0.192)$ & 0.366 & 0.000 & Yes \\
\hline & H5 & PC-> BG & 0.123 & 0.094 & $(-0.156,0.151)$ & -0.142 & 0.975 & Yes \\
\hline & H6 & FC-> BG & 0.126 & 0.105 & $(-0.153,0.159)$ & -0.013 & 0.567 & No \\
\hline & H7 & CC-> BG & 0.146 & 0.147 & $(0.224,0.233)$ & 0.072 & 0.273 & No \\
\hline
\end{tabular}

Note: In Henseler's MGA method, the $p$ value lower than 0.05 or higher than 0.95 indicates at the $5 \%$ level significant differences between specific path coefficients across two groups. 
